\title{
Discovery and verification of gelsolin as a potential biomarker of colorectal adenocarcinoma in a Chinese population: Examining differential protein expression using an ITRAQ labelling-based proteomics approach
}

\author{
Nai-Jun Fan PhD ${ }^{1}$, Chun-Fang Gao MD¹, Chang-Song Wang PhD², Jing-Jing Lv PhD', Guang Zhao PhD', \\ Xin-Hua Sheng PhD ${ }^{1}$, Xiu-Li Wang MD ${ }^{1}$, Dong-Hui Li MD ${ }^{1}$, Qing-Yin Liu MD ${ }^{3}$, Jian Yin MD²
}

N-J Fan, C-F Gao, C-S Wang, et al. Discovery and verification of gelsolin as a potential biomarker of colorectal adenocarcinoma in a Chinese population: Examining differential protein expression using an iTRAQ labelling-based proteomics approach. Can J Gastroenterol 2012;26(1):41-47.

OBJECTIVE: To identify and validate potential biomarkers of colorectal adenocarcinoma using a proteomic approach.

METHODS: Multidimensional liquid chromatography/mass spectrometry was used to analyze biological samples labelled with isobaric mass tags for relative and absolute quantitation to identify differentially expressed proteins in human colorectal adenocarcinoma and paired normal mucosa for the discovery of cancerous biomarkers. Cancerous and noncancerous samples were compared using online and offline separation. Protein identification was performed using mass spectrometry. The downregulation of gelsolin protein in colorectal adenocarcinoma samples was confirmed by Western blot analysis and validated using immunohistochemistry.

RESULTS: A total of 802 nonredundant proteins were identified in colorectal adenocarcinoma samples, 82 of which fell outside the expression range of 0.8 to 1.2 , and were considered to be potential cancer-specific proteins. Immunohistochemistry revealed a complete absence of gelsolin expression in $86.89 \%$ of samples and a reduction of expression in $13.11 \%$ of samples, yielding a sensitivity of $86.89 \%$ and a specificity of $100 \%$ for distinguishing colorectal adenocarcinoma from normal tissue.

CONCLUSIONS: These findings suggest that decreased expression of gelsolin is a potential biomarker of colorectal adenocarcinoma.

Key Words: Biomarker; Colorectal cancer; Gelsolin; Proteomic
La découverte et la vérification de la gelsoline comme biomarqueur potentiel de l'adénocarcinome colorectal au sein d'une population chinoise : l'examen de l'expression protéique différentielle au moyen de la protéomique par marquage iTRAQ

OBJECTIF : Identifier et valider les biomarqueurs potentiels de l'adénocarcinome colorectal au moyen de la protéomique.

MÉTHODOLOGIE : Les chercheurs ont utilisé la chromatographie liquide multidimensionnelle et la spectrométrie de masse pour analyser des échantillons biologiques marqués par masse isobare afin d'obtenir une quantification relative et absolue pour parvenir à la détermination différentielle des protéines exprimées dans les adénocarcinomes colorectaux humains et la muqueuse normale appariée, afin de déceler les biomarqueurs cancéreux. Ils ont comparé des échantillons cancéreux et non cancéreux au moyen d'une séparation virtuelle et réelle. Ils ont identifié les protéines par spectrométrie de masse. Ils ont confirmé la régulation à la baisse de la protéine de gelsoline dans les échantillons d'adénocarcinome colorectal par transfert Western et l'ont validée par immunohistochimie.

RÉSULTATS : Au total, les chercheurs ont repéré 802 protéines non redondantes dans des échantillons d'adénocarcinome colorectal, dont 82 se situaient hors de la plage d'expression de 0,8 à 1,2 et étaient considérées comme des protéines potentiellement spécifiques au cancer. L'immunohistochimie a révélé une absence complète de l'expression de gelsoline dans $86,89 \%$ des échantillons et une réduction de l'expression dans $13,11 \%$ des échantillons, pour une sensibilité de $86,89 \%$ et une spécificité de $100 \%$ à distinguer l'adénocarcinome colorectal des tissus normaux.

CONCLUSIONS : Selon ces observations, une diminution de l'expression de gelsoline serait un biomarqueur potentiel de l'adénocarcinome colorectal.

products and provides additional insight into post-translational modifications that regulate cellular functions, thereby complementing genomic analyses. The identification of differentially expressed proteins in CRC using proteomics suggests that expression patterns of proteins may have some utility in the discovery of cancer biomarkers.

Differential tagging with isotopic reagents, such as isotope-coded affinity tags (3), or the more recent variation that uses isobaric tags for relative and absolute quantitation (iTRAQ) reagents followed by multidimensional liquid chromatography (LC) and tandem MS/MS analysis, is emerging as a powerful methodology in the search for disease biomarkers. Many recent studies (4-11) using iTRAQ reagents resulted in the identification and relative quantification of proteins that led to the discovery of potential cancer markers for prostate, radiotherapy-resistant, renal cell, lung, oral, head and neck, breast and gene expression networks, proteomics links these networks to protein

${ }^{1}$ Anal-Colorectal Surgery Institute; ${ }^{2}$ Department of Pathology; ${ }^{3}$ Department of Clinical Laboratory, 150th Hospital of PLA, LuoYang, China

Correspondence and reprints: Dr Chun-Fang Gao, 150th Hospital of PLA, No.1, HuaXia Road, Luoyang, Henan 47 1000, China.

Telephone 86-379-64169327, fax 86-379-64169112, e-mail chunfanggao@126.com

Received for publication March 23, 2011. Accepted June 8, 2011 
TABLE 1

Gelsolin expression in colorectal cancer patients $(n=61)$

\begin{tabular}{|c|c|c|c|c|}
\hline \multirow[b]{2}{*}{ Characteristics } & \multirow[b]{2}{*}{$\begin{array}{l}\text { Cases } \\
(n=61)\end{array}$} & \multicolumn{2}{|c|}{ Gelsolin expression } & \multirow[b]{2}{*}{$\mathbf{P}$} \\
\hline & & $\begin{array}{c}\text { Absent } \\
(n=53)\end{array}$ & $\begin{array}{c}\text { Reduced } \\
(n=8)\end{array}$ & \\
\hline Sex & & & & $0.975^{\star}$ \\
\hline Male & 34 & 29 & 5 & \\
\hline Female & 27 & 24 & 3 & \\
\hline Age, years, mean \pm SD & $61.00 \pm 9.33$ & $61.79 \pm 7.58$ & $55.75 \pm 16.82$ & $0.348^{\dagger}$ \\
\hline Histological differentiatio & & & & $0.409^{*}$ \\
\hline Poorly differentiated & 19 & 15 & 4 & \\
\hline $\begin{array}{l}\text { Moderately } \\
\text { differentiated }\end{array}$ & 42 & 38 & 4 & \\
\hline Well-differentiated & 0 & 0 & 0 & \\
\hline TNM stage & & & & $0.164^{\star \ddagger}$ \\
\hline 1 & 13 & 12 & 1 & \\
\hline II & 20 & 19 & 1 & \\
\hline III & 18 & 14 & 4 & \\
\hline IV & 10 & 8 & 2 & \\
\hline Histological classificatior & & & & $<0.0001^{\star \S}$ \\
\hline Adenocarcinoma & 49 & 47 & 2 & \\
\hline $\begin{array}{l}\text { Mucinous } \\
\text { adenocarcinoma }\end{array}$ & 10 & 6 & 4 & \\
\hline $\begin{array}{l}\text { Signet-ring cell } \\
\text { carcinoma }\end{array}$ & 2 & 0 & 2 & \\
\hline $\begin{array}{l}\text { Undifferentiated } \\
\text { carcinoma }\end{array}$ & 0 & 0 & 0 & \\
\hline Tumour localization & & & & $0.474^{*}$ \\
\hline Colon & 18 & 17 & 1 & \\
\hline Rectum & 43 & 36 & 7 & \\
\hline
\end{tabular}

Data presented as $n$ unless otherwise indicated. ${ }^{*}$ Determined using $x^{2}$ test (continuity correction); ${ }^{\dagger}$ Determined using $\mathrm{t}$ test; ${ }^{\ddagger}$ Given the limited sample size, patients were combined: stage I and II as the early stage group, stage III and IV as the advanced stage group; ${ }^{\S}$ Mucinous adenocarcinoma, signet-ring cell carcinoma and undifferentiated carcinoma were combined into one group because of the limited sample size. TNM Tumour, node, metastasis

hepatocellular cancers. To the best of our knowledge, iTRAQ reagents have seldom been used in biomarker discovery studies in CRC.

In the present study, we used iTRAQ labelling in combination with two-dimensional (2D) liquid chromatography (LC) and MS to identify potential biomarkers of CRC by comparing protein profiles of tumour tissue with paired normal mucosa, which in turn may facilitate the early diagnosis of CRC. Some of the proteins identified were confirmed by Western blot analysis and immunohistochemistry (IHC). These approaches ensure that the selected proteins demonstrated a consistent pattern of differential expression in CRC and significantly increased the confidence of the observations obtained from the iTRAQ analysis. In addition to their potential utility as biomarkers for CRC, these proteins also provide valuable insight into the still unknown molecular networks and mechanisms that govern the normal-to-malignant conversion of the epithelium.

\section{Patients}

\section{METHODS}

Data from all CRC patients who underwent surgical resection at the 150th Hospital, PLA, Luoyang, China, between January and June 2010, were retrieved from the files of the department of pathology. The criteria for inclusion in the study were as follows: presence of sporadic tumours without evidence of polyposis or familial predisposition syndrome; availability of clinical information and tumour stage; availability of tissue material; and a diagnosis of colorectal adenocarcinoma. The criteria for exclusion from the study were the presence of palindromic or metastatic tumour(s), and patients receiving antitumour therapy including chemotherapy, radiotherapy or biotherapy. Of the patients fulfilling these criteria, 66 cases were randomly selected. The patient consent forms and tissue-banking procedures were approved by the Research Ethics Board of the 150th Hospital. Histological diagnosis of each sample was confirmed using microscopic examination of hematoxylin and eosin-stained sections obtained during radical correction surgery.

\section{Tissue material}

Paired tissue samples of primary tumours (obtained from surgical resections) and their normal mucosa (not less than $5 \mathrm{~cm}$ from the cancerous margin) were flash frozen in liquid nitrogen within 20 min of devitalization after radical correction surgery $(n=5$, used for iTRAQ and Western blot analysis) or fixed in buffered formalin and embedded in paraffin ( $n=61$, used for IHC).

The frozen samples were sectioned and stored at $-80^{\circ} \mathrm{C}$. The tissue from the opposite face of the histological section was then washed three times in approximately $1 \mathrm{~mL}$ of phosphate buffered saline (PBS) containing a mixture of protease inhibitors as described previously (12) (1 mM 4-[2-aminoethyl] benzenesulfonyl fluoride, $10 \mu \mathrm{M}$ leupeptin, $1 \mu \mathrm{g} / \mathrm{mL}$ aprotinin and $1 \mu \mathrm{M}$ pepstatin). The washed tissues were then homogenized in $0.5 \mathrm{~mL}$ of PBS containing protease inhibitors using a handheld homogenizer. These homogenates were then flash frozen in liquid nitrogen and stored at $-80^{\circ} \mathrm{C}$ until use.

Neoplastic lesions were classified histologically according to the Vienna classification of digestive epithelial neoplasia (13). The tumour, node, metastsis (TNM) stage of the adenocarcinomas was determined according to the American Joint Committee on Cancer classification (14). The following data were recorded: localization, histological classification and TNM stage for adenocarcinomas (Table 1).

\section{Protein digest, iTRAQ labelling and strong cation-exchange fractionation}

Cancerous and paired normal flash-frozen samples from five patients were thawed and clarified by centrifugation, and protein concentrations were determined with a Bradford-type assay using a protein quantification reagent (Bio-Rad, USA). Cancerous samples and paired normal samples were pooled in equal parts and precipitated.

The samples (100 mg each) were reduced, alkylated and digested with trypsin overnight at a protein:enzyme ratio of $20: 1$ at $37^{\circ} \mathrm{C}$. Each digest was concentrated to a volume of $15 \mu \mathrm{L}$ in a speed vacuum followed by the addition of $15 \mu \mathrm{L}$ of $1 \mathrm{M}$ TEAB. The iTRAQ reagent was dissolved in $70 \mu \mathrm{L}$ of ethanol and added to the digest, and the mixture was incubated at room temperature for $1 \mathrm{~h}$. Cancer and normal samples labelled with different iTRAQ reagents were mixed and dried to a volume of $50 \mu \mathrm{L}$. The combined peptide mixture was fractionated by strong cation-exchange (SCX) chromatography on an UltiMate highperformance liquid chromatography (HPLC) system (LC Packings, The Netherlands) using a polysulfoethyl A column $(2.1100 \mathrm{~mm}, 5 \mathrm{~m}, 300 \AA$ [PolyLC, USA]). The sample was subsequently dissolved in $1 \mathrm{~mL}$ of SCX loading buffer (25\% v/v acetonitrile, $10 \mathrm{mM} \mathrm{KH}_{2} \mathrm{PO}_{4}$ [pH 2.8]), and $\mathrm{pH}$ was adjusted to 2.8 by adding $1 \mathrm{M}$ phosphoric acid. The entire sample was loaded onto the column and washed isocratically for $30 \mathrm{~min}$ at a flow rate of $200 \mu \mathrm{L} / \mathrm{min}$. Peptides were eluted with a linear gradient of $0 \mathrm{mM}$ to $500 \mathrm{mM} \mathrm{KCl} \mathrm{(25 \%} \mathrm{v/v} \mathrm{acetonitrile,} 10 \mathrm{mM} \mathrm{KH}_{2} \mathrm{PO} 4, \mathrm{pH}$ 2.8) over $30 \mathrm{~min}$ at a flow rate of $200 \mu \mathrm{L} / \mathrm{min}$. The absorbance at $214 \mathrm{~nm}$ was monitored, and 15 fractions were collected along the gradient.

\section{LC/MS analysis}

Each SCX fraction was dried down, dissolved in $0.1 \%$ formic acid and analyzed by MS (Qstar Pulsar [Applied Biosystems-MDS Sciex, USA) interfaced with an Agilent 1100 HPLC system. Peptides were separated on a reverse-phase column packed with $10 \mathrm{~cm}$ of $\mathrm{C} 18$ beads $(36,075 \mathrm{~m}$, $5 \mathrm{~m}, 120 \AA$, YMC ODS-AQ [Waters Associates, USA]) with an emitter tip (New Objective, USA) attached. The peptides retained were washed using a gradient ranging from $5 \%$ to $40 \%$ solvent B $(98 \%$ 
acetonitrile, $0.1 \%$ formic acid $)$ in solvent $\mathrm{A}$ ( $0.1 \%$ formic acid $)$ for 60 min at a flow rate of $300 \mathrm{~nL} / \mathrm{min}$. Survey scans were acquired from a spectra of $400 \mathrm{~m} / \mathrm{z}$ to $1200 \mathrm{~m} / \mathrm{z}$, with up to three precursors selected for MS/MS using a dynamic exclusion of $45 \mathrm{~s}$. Rolling collision energy was used to promote fragmentation, with the collision energy range $20 \%$ higher than that used for unlabelled peptides because of the presence of iTRAQ tags.

\section{Data analysis}

The MS/MS spectra data were extracted and searched for in the Uniprot-Sprot database (version 4, total number of entries: 230,093, entries for Homo sapiens: 14,515) using ProteinPilot version 3.0 software (revision 114732 [Applied Biosystems, USA]) with the Paragon method using the following search parameters: $H$ sapiens as species, trypsin as enzyme (one missed cleavage allowed), cysteine static modification with methylmethanethiosulfate and iTRAQ (peptide labelled at the $\mathrm{N}$ terminus and lysine) as sample type. Mass tolerance was set to 0.15 atomic mass units for the precursor, and 0.1 atomic mass units for the fragment ions. The raw peptide identification results from the Paragon algorithm (Applied Biosystems, USA) searches were further processed by the Pro Group algorithm (Applied Biosystems, USA) within the ProteinPilot software before final display. The Pro Group algorithm uses the peptide identification results to determine the minimal set of proteins that can be reported for a given protein confidence threshold. For each protein, Pro Group algorithm reports two types of scores: unused ProtScore and total ProtScore. The total ProtScore is a measurement of all the peptide evidence for a protein, and is analogous to protein scores reported by other protein identification software packages. The unused ProtScore, however, is a measurement of all peptide evidence for a protein that is not better explained by a higher ranking protein. In other words, the unused ProtScore is calculated by using the unique peptides (peptides that are not used by the higher ranking protein) and is a true indicator of the presence of protein. This is how a single-protein member of a multiprotein family was isolated. The protein confidence threshold cut-off for the present study was ProtScore 2.0 (unused) with at least one peptide with $99 \%$ confidence. The mean, SD and P values to estimate statistical significance of the protein changes were calculated using Pro Group software. Differentially expressed proteins (ratio $>1.2$ or $<0.8$ ) that were consistent between two independent biological experiments were manually validated and quantified. Peak areas for each of the signature ions (113 and 114) were obtained and corrected according to the manufacturer's instructions to account for isotopic overlap. Only signature ions with intensities $<1500$ counts were used for quantitation. When intesities of the signature ions were $>1500$ counts, $1: 1$ ratios were generated due to detector saturation.

\section{Western blot analysis}

To verify the iTRAQ data, samples $(1 \mu \mathrm{g})$ were separated by $12 \%$ sodium dodecyl polyacryamide gel electrophoresis and transferred to polyvinylidene fluoride membranes. After blocking for $1 \mathrm{~h}$ at room temperature with blocking buffer $(20 \mathrm{mM}$ Tris- $\mathrm{HCl}$ pH 7.5, $100 \mathrm{mM}$ $\mathrm{NaCl}, 0.1 \%$ Tween 20 [TBS/Tween 20]) and 5\% nonfat milk powder, membranes were incubated overnight at $4^{\circ} \mathrm{C}$ in a $1: 25,000$ dilution of primary antibody (rabbit monoclonal antibody [Abcam (Hong Kong) Ltd, Hong Kong, China) in blocking buffer. The membranes were washed with TBS/Tween 20, incubated for $1 \mathrm{~h}$ at room temperature in secondary antibody (donkey antirabbit immunoglobulin G, Santcruz Biotech, USA) at a 1:2000 dilution in blocking buffer and, finally, washed with TBS/Tween 20. Blots were developed using Immun-Star TMAP Substrate Pack (BioRad, USA) and scanned on an Epson Scan (Agilent Technologies, USA) scanner within the linear range of detection.

\section{Evaluation of immunohistochemical staining}

A standard two-step indirect streptavidin-biotin method was applied to sections ( $3 \mu \mathrm{m}$ thick) of deparaffinized tissue (StreptABComplex/ HRP Duet, Mouse/Rabbit Amplification kit, ZhongShan Company,

\begin{tabular}{|c|c|c|c|}
\hline CRC & & iTRAQ113 & \\
\hline & $\rightarrow$ and digest & $\rightarrow$ Combined & $\rightarrow$ LC-MS-MS \\
\hline
\end{tabular}

Figure 1) Mass spectrometry (MS)-based approach (isobaric tags for relative and absolute quantitation [iTRAQ]) to quantitative analysis of colorectal cancer (CRC). Proteins were extracted from CRC tissue and paired normal mucosa, digested with trypsin, labelled with iTRAQ reagent and combined. The resulting peptides were fractioned using strong cation exchange chromatography and analyzed by liquid chromatography (LC)-tandem MS-MS

China). After autoclave sterilizer antigen retrieval (5 min in sodium citrate buffer [pH 7.3]) and peroxidase quenching with 3\% hydrogen peroxide for $15 \mathrm{~min}$, a 1:150 dilution of antigelsolin antibody (Abcam (Hong Kong) Ltd, Hong Kong, China) was applied overnight at $4^{\circ} \mathrm{C}$. Biotinylated goat immunoglobulin $\mathrm{G}$ and streptavidinbiotin complexes were then applied for $30 \mathrm{~min}$ each. Sections were counterstained with Mayer's hematoxylin. Primary antibody omission served as a negative control. Smooth muscle cells and endothelial cells served as an internal positive control.

To evaluate the percentage of gelsolin-positive cells, the entire section was first scanned to determine the overall distribution of gelsolin expression within the tumour and its degree of heterogeneity; then, the percentage of gelsolin-positive cells was determined in representative areas by examining 10 randomly selected microscopic fields (magnification $\times 400$ ) of each tissue section. Observations were made by two different observers who were blinded to clinical outcome (ie, the slides were coded, and the pathologists did not have previous knowledge of the local tumour burden, lymphonodular spread and grading of the tissue samples while scoring the immunoreactivity). Sections were scored positive if epithelial cells showed immunopositivity in the cytoplasm, plasma membrane and/or nucleus when judged independently by two scorers. A grading system was used to express the proportion of positive cells in each case as follows: grade $(G) 0$, negative; $\mathrm{G} 1,<25 \%$ positive cells; $\mathrm{G} 2,25 \%$ to $50 \%$ positive cells; $\mathrm{G} 3$, $50 \%$ to $75 \%$ positive cells; and G4, $>75 \%$ positive cells per lesion. In each type of lesion, results were expressed as the percentage of cases of each grade.

\section{Statistical analysis}

ProteinPilot software using the Paragon method was used to analyze MS/MS spectra. Results of IHC were analyzed using the $\chi^{2}$ test (continuity correction) or $t$ test. Differences between two means with $\mathrm{P}<0.05$ were considered to be statistically significant.

\section{RESULTS}

Quantitative proteomics analysis of CRC and normal tissue In the present study, iTRAQ-based stable isotope labelling of colorectal tissues was performed to identify dysregulated proteins in CRC. The experimental strategy is shown in Figure 1.

After labelling with iTRAQ reagents (113 for cancer samples and 114 for normal samples), the two samples were mixed and analyzed by LC-MS/MS. The MS/MS fragmentation of the iTRAQ-labelled peptides resulted in signature peaks (at 113.1 and 114.1) for quantitation, while the fragmentation along the peptide backbone resulted in band y-type fragments, which were used to identify the peptide sequence. Only proteins with at least two peptides per protein and a high annotation confidence ( $\geq 95 \%$ ) were considered, resulting in a total of 802 nonredundant proteins, which included structural proteins, signalling components, enzymes, receptors, transcription factors and chaperones. Eighty-two altered proteins outside the expression range of 0.8 to 1.2 were considered to be potential CRCspecific proteins (Appendix). Among these 82 proteins, gelsolin was specifically identified as a potential biomarker given the following: gelsolin, one of the major actin-binding proteins, is involved in the regulation of actin cytoskeleton organization via its severing and capping activity of actin filaments (15); and loss of gelsolin, a tumour suppressor, 


\begin{tabular}{|c|c|c|c|c|}
\hline \multirow[b]{2}{*}{ Peptide sequence } & \multicolumn{2}{|c|}{ Peptide } & \multirow{2}{*}{$\begin{array}{l}\text { Protein } \\
\text { ratio }^{\dagger}\end{array}$} & \multirow[b]{2}{*}{$\mathbf{P}$} \\
\hline & Confidence, $\%$ & Ratio $^{\dagger}$ & & \\
\hline AGALNSNDAFVLK & 99 & 0.4295 & 0.5012 & $<0.0001^{\ddagger}$ \\
\hline EPAHLMSLFGGKPMIIYK & 99 & 0.2144 & & \\
\hline EVQGFESATFLGYFK & 99 & 0.4734 & & \\
\hline HVVPNEVVVQR & 99 & 0.1181 & & \\
\hline QTQVSVLPEGGETPLFK & 99 & 0.3839 & & \\
\hline SEDCFILDHGKDGK & 99 & 0.2984 & & \\
\hline TGAQELLR & 99 & 0.3147 & & \\
\hline $\begin{array}{l}\text { TPSAAYLWVGTGASEAEK } \\
\text { TGAQELLR }\end{array}$ & 99 & 0.9661 & & \\
\hline YIETDPANR & 99 & 0.5898 & & \\
\hline
\end{tabular}

${ }^{*}$ Applied Biosystems, USA; $^{\dagger}$ Cancerous/normal; ${ }^{\ddagger}$ Actual value $9.04 \times 10^{-5}$

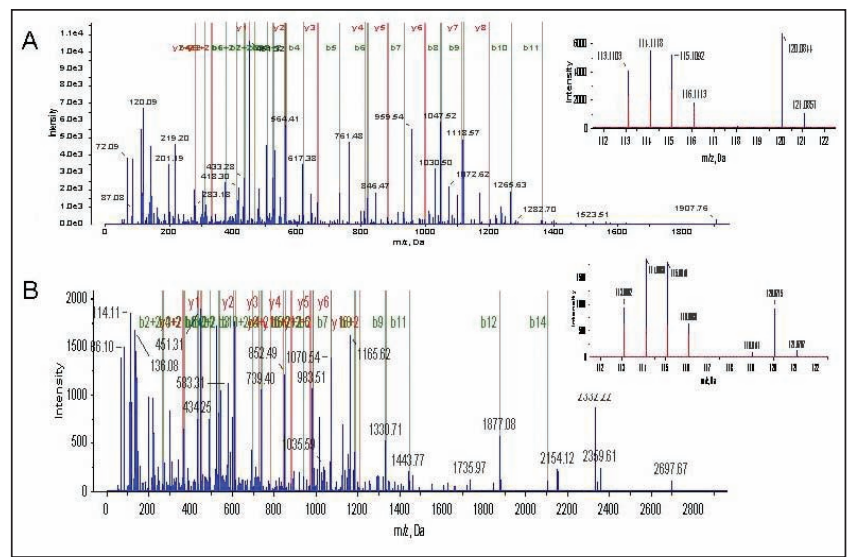

Figure 2) Representative tandem mass spectrometry (MS/MS) spectra for peptides derived from gelsolin. For each MS/MS spectrum, $b$ - and $y$-type fragment ions enabled peptide identification, whereas the peak areas of each of the iTRAQ signature ions (insets) enable quantification of the peptides and protein. A MS/MS spectrum of the peptide sequence AGALNSNDAFVLK from gelsolin. B MS/MS spectrum of the peptide sequence EPAHLMSLFGGKPMIIYK from gelsolin. Colorectal cancer and the paired normal sample were iTRAQ tagged by 113 and 114 , respectively. The isobaric tag 115 and 116 were used in another experiment of esophageal carcinoma. iTRAQ Isobaric tags for relative and absolute quantitation

is one of the most frequently occurring molecular defects in ovarian, breast, colon and pancreatic cancers (16-19). Gelsolin peptide sequences, peptide confidence, peptide ratios, protein ratios and $\mathrm{P}$ values calculated by ProteinPilot are presented in Table 2.

According to the protein sequence coverage map, protein sequences with matching peptides could be divided into groups with the highest confidence, moderate confidence, lowest confidence and the portions of the protein sequence for which no peptides were identified. The MS/MS spectra of two matching peptides (AGALNSNDAFVLK and EPAHLMSLFGGKPMIIYK) with the highest confidence are shown in Figure 2, with the peaks for the signature ions shown in the insets.

\section{Western blot analysis}

Western blot experiments were performed to validate the iTRAQ assay results. Based on a literature search, gelsolin was chosen. Gelsolin was detected by Western blot from the pooled sample used in a 2D LC-MS/MS experiment. Gelsolin is considered to be downregulated in CRC based on gray scale analysis of the protein strap, which was consistent with the discovery experiment (Figure 3).

\begin{tabular}{|l|llll|}
\hline A & B & C & D & E \\
\end{tabular}

Figure 3) Validation of gelsolin by Western blot. Western blot results using frozen tissue samples used in the discovery experiment. A $\beta$-actin in normal sample. B $\beta$-actin in cancerous sample. C Negative control. D Gelsolin in normal sample. E Gelsolin in cancerous sample. The gray scale in the cancerous sample (E) is 0.48 of that of the normal sample (D)

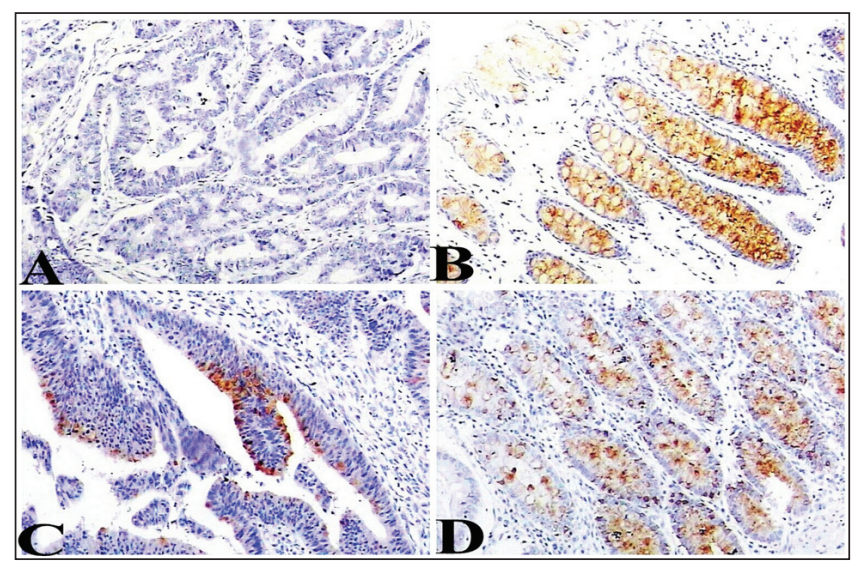

Figure 4) Validation of gelsolin using immunohistochemical staining. A Cancerous sample showing a complete absence of detection. B Paired normal mucosa of sample A showing an expression of grade 4. C Cancerous sample showing decreased expression from grade 3 to grade 1 compared with sample $\mathbf{D}$ (paired normal mucosa of sample C). All images original magnification $\times 100$

\section{Immunohistochemical staining}

Gelsolin expression was tested using IHC in 61 primary human colorectal adenocarcinomas and their paired normal mucosa for further validation. Gelsolin expression was detected in all normal colon samples examined (61 of 61 [100\%]) (Figure 4B and 4D). In epithelial cells, gelsolin was detected in both enterocytes and goblet cells. Gelsolin showed cytoplasmic expression and, in part of the cytoplasm surrounding the mucus vacuoles, no nuclear labelling was detected. Compared with normal mucosa, gelsolin expression was decreased in all tumours analyzed (61 of 61 [100\%]) (Figure 4A and 4C), resulting either in a complete absence of detection in $86.89 \%$ (53 of 61) of samples (Figure 4A) or in focal staining of clusters of tumour cells in $13.11 \%$ (eight of 61 ) of samples (Figure 4C). Gelsolin achieved a sensitivity of $86.89 \%$ and specificity of $100 \%$ in distinguishing colorectal adenocarcinoma from normal tissue.

In cancer samples (reduced expression in eight cases) with clusters of gelsolin-positive cells, the mean $( \pm \mathrm{SD})$ percentage of gelsolin-positive tumour cells was $21.18 \pm 7.73 \%$. The percentage of gelsolin-positive cells was reduced in cancer compared with paired normal mucosa $(\mathrm{P}=0.034$ [paired sample $t$ test]) (Figure 4C and 4D). No adenocarcinoma was scored as G4 (>75\% of positive cells) or G3 (50\% to $75 \%$ of positive cells), whereas $37.5 \%$ of cases (three of eight) were classified as G2 ( $25 \%$ to $50 \%$ of positive cells) and $62.5 \%$ of the cases (five of eight) were classified as G1 ( $<25 \%$ of positive cells). Gelsolin-positive cells showed cytoplasmic expression in adenocarcinoma (three of eight samples [37.5\%]); mucinous adenocarcinoma (three of eight samples [37.5\%]); and signet-ring cell carcinoma (two of eight samples [25\%]). Compared with tumours devoid of expression, gelsolin expression tended to be reduced in mucinous adenocarcinoma and signet-ring cell carcinoma $(\mathrm{P}<0.0001)$. This decrease in gelsolin expression in CRC was not correlated with age, sex, histological differentiation, TNM stage or tumour localization (Table 1).

\section{DISCUSSION}

Compared with traditional proteomic methods, such as 2D gel analysis followed by MS/MS identification, the iTRAQ-coupled 2D-LC-MS/MS 
approach provides higher detection sensitivity and holds the promise of effectively depicting cellular protein profiles in tissue $(9,11,20)$. In recent years, this approach has been used in prostate, radiotherapyresistant, renal cell, lung, oral, head and neck, breast and hepatocellular cancers (4-11).

In the present study, we applied isobaric peptide tags (ie, iTRAQ) and multidimensional LC-MS/MS to identify proteins that are differentially expressed in CRC and paired normal mucosa samples. Differential gelsolin expression was validated by Western blot analysis and IHC. Because adenocarcinoma comprises more than $50 \%$ of CRCs, only colorectal adenocarcinoma was included in the present study.

Using a combination of subfractionation, iTRAQ-based labelling, 2D-LC peptide separation, MS and database searches for human proteins, 82 proteins altered outside the range of 0.8 to 1.2 were considered as potential CRC-specific proteins. Downregulation of gelsolin was confirmed by Western blot analysis and IHC. These serial studies suggest that combined proteomics and bioinformatics analysis can generate valid candidates that may be further evaluated for their role in the progression from normal tissue to adenocarcinoma. Although the validation of a protein cannot be extrapolated to the full protein list, it did suggest that the ITRAQ results were reliable.

Abnormal expression of gelsolin has been reported in many types of tumours. The expression of gelsolin has been reported to be frequently silenced in various cancers $(16,18,21-27)$. Conversely, overexpression of gelsolin has been found to be a negative prognostic predictor in a subpopulation of patients with nonsmall cell lung cancer, urothelial cancer, and $\mathrm{EGFR}^{+} / \mathrm{erB}-2^{+}$breast cancer $(25,28,29)$. Gelsolin regulates the architecture and dynamics of cells by capping, severing and nucleating actin filaments. However, the precise molecular mechanism behind the reduction of gelsolin expression has not yet been clarified $(22,30)$. Despite the high incidence of CRC, only a few contradictory studies regarding the expression of gelsolin in this type of malignancy and its precursor lesions are available. One IHC study (31) reported weak gelsolin staining in 30 normal human colon mucosa and 22 adenocarcinoma samples. In contrast, another report based on 69 primary human colon adenocarcinomas and their paired normal mucosa (18) showed decreased gelsolin expression in all tumours analyzed, resulting in either a complete absence of detection in $34.8 \%$ of cases, or in focal staining of clusters of tumour cells in $65.2 \%$ of cases. This latter result was supported by DNA microarray studies that reported reduced expression of gelsolin complementary DNA in colon cancer compared with normal colon tissue $(32,33)$. Furthermore, gelsolin expression and its subcellular

\begin{tabular}{lll}
$\begin{array}{l}\text { APPENDIX } \\
\text { Dysregulated proteins (n=82) in colorectal adenocarcinoma } \\
\text { identified using an iTRAQ-based proteomic approach }\end{array}$ \\
\hline \multicolumn{1}{l}{$\begin{array}{l}\text { Accession } \\
\text { Protein }\end{array}$} & $\begin{array}{l}\text { Expression } \\
\text { level in } \\
\text { cancer }\end{array}$ \\
\hline Histone H3.3 & sp|P84243|H33_HUMAN & Increased \\
Neutrophil defensin 3 & sp|P39019|RS19_HUMAN & Increased \\
40S ribosomal protein S19 & sp|Q99715|COCA1_HUMAN & Increased \\
Collagen alpha-1(XII) chain & sp|P62805|H4_HUMAN & Increased \\
Histone H4 & sp|P13639|EF2_HUMAN & Increased \\
Elongation factor 2 & sp|Q99877|H2B1N_HUMAN & Increased \\
Histone H2B type 1-N & sp|P07355|ANXA2_HUMAN & Increased \\
Annexin A2 & sp|P10809|CH60_HUMAN & Increased \\
60 kDa heat shock protein, & & \\
\multicolumn{1}{c}{ mitochondrial } & sp|P02675|FIBB_HUMAN & Increased \\
Fibrinogen beta chain & sp|P11021|GRP78_HUMAN & Increased \\
78 kDa glucose-regulated protein & sp|P07237|PDIA1_HUMAN & Increased \\
Protein disulfide-isomerase & sp|P19971|TYPH_HUMAN & Increased \\
Thymidine phosphorylase & sp|P24821|TENA_HUMAN & Increased \\
Tenascin & sp|O75369|FLNB_HUMAN & Increased \\
Filamin-B & &
\end{tabular}

distribution seem to correlate with metastatic potential in human colon adenocarcinoma cells (15). Using 2D-LC-MS/MS, gelsolin expression was found to be decreased in CRC in the present study. This result was further validated by Western blot analysis and IHC, with gelsolin expression tested using IHC in 61 primary human CRC and paired normal mucosa samples. Gelsolin expression was detected in all normal colon and rectum samples examined. Compared with normal mucosa, gelsolin expression was decreased in all tumours analyzed (61 of 61 [100\%]), resulting either in a complete absence of detection in $86.89 \%$ ( 53 of 61 ) of samples or in focal staining of clusters of tumour cells in $13.11 \%$ (eight of 61 ) of samples. The rate of complete absence of detection surpasses the rate reported by Gay et al (18). In cases of reduced gelsolin expression, $62.5 \%$ showed mucinous adenocarcinoma and signet-ring cell carcinoma, while $37.5 \%$ of cases showed adenocarcinoma. This difference was statistically significant $(\mathrm{P}<0.0001)$, which suggests that the role of gelsolin in CRC may correlate with histological classification.

\section{CONCLUSION}

The results presented reinforce the idea that iTRAQ and 2D-LC-MS/ MS represent an effective and reliable proteomic process in cancer biomarker discovery; the downregulation of gelsolin expression is a general mechanism during the transition from normal tissue to cancer; and that gelsolin may be a potential biomarker for colorectal adenocarcinoma in the Chinese population.

COMPETING INTERESTS: The authors have no conflicts of interest to declare.

AUTHORS' CONTRIBUTIONS: Nai-jun Fan was responsible for the conception and design of this study, providing samples and clinical data, drafting and revising the article and performing the experiments. Chun-fang Gao contributed to the design of this study. Chang-song Wang, Jian-Yin and Qing-yin Liu contributed to the validation of gelsolin. JingJing Lv, Guang Zhao, Xin-hua Sheng, Xiu-li Wang and Dong-hui Li contributed to samples and clinical data collection. All authors have read and approved the final manuscript.

ACKNOWLEDGEMENTS: The authors thank Xiao-Hui Liu and Hong Jin (Fu Dan University, ShangHai, China) for their expertise in iTRAQ and 2D-LC-MS/MS, and Fang-Yi Han and Jing-Cui (Xin Xiang Medical College, XinXiang, China) for their expertise in Western-blot analysis.

\begin{tabular}{lll}
\hline Protein & Accession & $\begin{array}{l}\text { Expression } \\
\text { level in } \\
\text { cancer }\end{array}$ \\
\hline Keratin, type I cytoskeletal 1 & sp|P05783|K1C18_HUMAN & Increased \\
Stress-70 protein, mitochondrial & sp|P38646|GRP75_HUMAN & Increased \\
Fibrinogen alpha chain & sp|P02671|FIBA_HUMAN & Increased \\
Macrophage-capping protein & sp|P40121|CAPG_HUMAN & Increased \\
Periostin & sp|Q15063|POSTN_HUMAN & Increased \\
Cytoskeleton-associated protein 4 & sp|Q07065|CKAP4_HUMAN & Increased \\
Protein disulfide-isomerase A3 & sp|P30101|PDIA3_HUMAN & Increased \\
SH3 domain-binding glutamic & sp|Q9H299|SH3L3_HUMAN & Increased \\
\multicolumn{1}{c|}{ acid-rich-like protein 3 } & sp|P04083|ANXA1_HUMAN & Increased \\
Annexin A1 & sp|P02679|FIBG_HUMAN & Increased \\
Fibrinogen gamma chain & sp|P13796|PLSL_HUMAN & Increased \\
Plastin-2 & sp|P35579|MYH9_HUMAN & Increased \\
Myosin-9 & sp|Q14697|GANAB_HUMAN & Increased \\
Neutral alpha-glucosidase AB & sp|P08708|RS17_HUMAN & Increased \\
40S ribosomal protein S17 & sp|P02768|ALBU_HUMAN & Increased \\
Serum albumin & sp|Q15149|PLEC1_HUMAN & Increased \\
Plectin-1 & sp|P05787|K2C8_HUMAN & Increased \\
Keratin, type II cytoskeletal 8 & & \\
& &
\end{tabular}


APPENDIX - cONTINUED

Dysregulated proteins $(n=82)$ in colorectal adenocarcinoma identified using an iTRAQ-based proteomic approach

\begin{tabular}{|c|c|c|}
\hline Protein & Accession & $\begin{array}{l}\text { Expression } \\
\text { level in } \\
\text { cancer }\end{array}$ \\
\hline Heat shock protein HSP 90-alpha & sp|P07900|HS90A_HUMAN & Increased \\
\hline Fibronectin & sp|P02751|FINC_HUMAN & Increased \\
\hline Myosin-11 & sp|P35749|MYH11_HUMAN & Decreased \\
\hline Hemoglobin subunit alpha & sp|P69905|HBA_HUMAN & Decreased \\
\hline PDZ and LIM domain protein 7 & sp|Q9NR12|PDLI7_HUMAN & Decreased \\
\hline Collagen alpha-1(VI) chain & sp|P12109|CO6A1_HUMAN & Decreased \\
\hline $\begin{array}{l}\text { Neuroblast differentiation- } \\
\text { associated protein AHNAK }\end{array}$ & sp|Q09666|AHNK_HUMAN & Decreased \\
\hline Synaptopodin-2 & sp|Q9UMS6|SYNP2_HUMAN & Decreased \\
\hline Alpha-actinin-1 & sp|P12814|ACTN1_HUMAN & Decreased \\
\hline $\begin{array}{l}\text { ATP synthase subunit beta, } \\
\text { mitochondrial }\end{array}$ & sp|P06576|ATPB_HUMAN & Decreased \\
\hline Collagen alpha-1(XIV) chain & sp|Q05707|COEA1_HUMAN & Decreased \\
\hline Tensin-1 & sp|Q9HBLO|TENS1_HUMAN & Decreased \\
\hline Decorin & sp|P07585|PGS2_HUMAN & Decreased \\
\hline Collagen alpha-2(VI) chain & sp|P12110|CO6A2_HUMAN & Decreased \\
\hline Talin-1 & sp|Q9Y490|TLN1_HUMAN & Decreased \\
\hline Gelsolin & sp|P06396|GELS_HUMAN & Decreased \\
\hline $\begin{array}{l}\text { Myosin light chain kinase, } \\
\text { smooth muscle }\end{array}$ & sp|Q15746|MYLK_HUMAN & Decreased \\
\hline Desmuslin & sp|O15061|DMN_HUMAN & Decreased \\
\hline $\begin{array}{l}\text { ATP synthase subunit alpha, } \\
\text { mitochondrial }\end{array}$ & sp|P25705|ATPA_HUMAN & Decreased \\
\hline $\begin{array}{l}\text { Sorbin and SH3 domain- } \\
\text { containing protein } 1\end{array}$ & sp|Q9BX66|SRBS1_HUMAN & Decreased \\
\hline Ig gamma-1 chain $\mathrm{C}$ region & sp|P01857|IGHG1_HUMAN & Decreased \\
\hline Desmoplakin & sp|P15924|DESP_HUMAN & Decreased \\
\hline $\begin{array}{l}\text { Membrane primary amine } \\
\text { oxidase }\end{array}$ & sp|Q16853|AOC3_HUMAN & Decreased \\
\hline Lamin-A/C & sp|P02545|LMNA_HUMAN & Decreased \\
\hline Lumican & sp|P51884|LUM_HUMAN & Decreased \\
\hline $\begin{array}{l}\text { Polymerase I and transcript } \\
\text { release factor }\end{array}$ & sp|Q6NZI2|PTRF_HUMAN & Decreased \\
\hline Peroxiredoxin-2 & sp|P32119|PRDX2_HUMAN & Decreased \\
\hline Tropomyosin beta chain & sp|P07951|TPM2_HUMAN & Decreased \\
\hline Tropomyosin alpha-1 chain & sp|P09493|TPM1_HUMAN & Decreased \\
\hline Prolargin & sp|P51888|PRELP_HUMAN & Decreased \\
\hline $\begin{array}{l}\text { Myosin regulatory light } \\
\text { polypeptide } 9\end{array}$ & sp|P24844|MYL9_HUMAN & Decreased \\
\hline Profilin-1 & sp|P07737|PROF1_HUMAN & Decreased \\
\hline Vinculin & sp|P18206|VINC_HUMAN & Decreased \\
\hline Creatine kinase B-type & sp|P12277|KCRB_HUMAN & Decreased \\
\hline Filamin-C & sp|Q14315|FLNC_HUMAN & Decreased \\
\hline Calponin-1 & sp|P51911|CNN1_HUMAN & Decreased \\
\hline Mimecan & sp|P20774|MIME_HUMAN & Decreased \\
\hline Spectrin alpha chain, brain & sp|Q13813|SPTA2_HUMAN & Decreased \\
\hline Ig gamma-2 chain $\mathrm{C}$ region & sp|P01859|IGHG2_HUMAN & Decreased \\
\hline $\begin{array}{l}\text { Glyceraldehyde-3-phosphate } \\
\text { dehydrogenase }\end{array}$ & sp|P04406|G3P_HUMAN & Decreased \\
\hline Ig kappa chain C region & sp|P01834|IGKC_HUMAN & Decreased \\
\hline Transgelin & sp|Q01995|TAGL_HUMAN & Decreased \\
\hline $\begin{array}{l}\text { Phosphatidylethanolamine- } \\
\text { binding protein } 1\end{array}$ & sp|P30086|PEBP1_HUMAN & Decreased \\
\hline Peroxiredoxin-5, mitochondrial & sp|P30044|PRDX5_HUMAN & Decreased \\
\hline EH domain-containing protein 2 & sp|Q9NZN4|EHD2_HUMAN & Decreased \\
\hline Tenascin-X OS=Homo sapiens & sp|P22105|TENX_HUMAN & Decreased \\
\hline
\end{tabular}

\begin{tabular}{lll}
\hline & Accession & $\begin{array}{l}\text { Expression } \\
\text { level in } \\
\text { cancer }\end{array}$ \\
Protein & sp|P21291|CSRP1_HUMAN & $\begin{array}{l}\text { Decreased } \\
\text { Cysteine and glycine-rich protein } 1\end{array}$ \\
Ig lambda chain C regions & sp|P01842|LAC_HUMAN & Decreased \\
Hemoglobin subunit beta & sp|P68871|HBB_HUMAN & Decreased \\
Heat shock 70 kDa protein 1 & sp|P08107|HSP71_HUMAN & Decreased \\
Filamin-C & sp|Q14315|FLNC_HUMAN & Decreased \\
Calponin-1 & sp|P51911|CNN1_HUMAN & Decreased \\
Spectrin alpha chain, brain & sp|Q13813|SPTA2_HUMAN & Decreased \\
Ig gamma-2 chain C region & sp|P01859|IGHG2_HUMAN & Decreased \\
Glyceraldehyde-3-phosphate & sp|P04406|G3P_HUMAN & Decreased \\
dehydrogenase & & \\
Ig kappa chain C region & sp|P01834||GKC_HUMAN & Decreased \\
Transgelin & sp|Q01995|TAGL_HUMAN & Decreased \\
Phosphatidylethanolamine- & sp|P30086|PEBP1_HUMAN & Decreased \\
binding protein 1 & & \\
Peroxiredoxin-5, mitochondrial & sp|P30044|PRDX5_HUMAN & Decreased \\
EH domain-containing protein 2 & sp|Q9NZN4|EHD2_HUMAN & Decreased \\
Tenascin-X OS= Homo sapiens & sp|P22105|TENX_HUMAN & Decreased \\
Cysteine and glycine-rich protein 1 1 & sp|P21291|CSRP1_HUMAN & Decreased \\
Ig lambda chain C regions & sp|P01842|LAC_HUMAN & Decreased \\
Hemoglobin subunit beta & sp|P68871|HBB_HUMAN & Decreased \\
Heat shock 70 kDa protein 1 & sp|P08107|HSP71_HUMAN & Decreased \\
Filamin-C & sp|Q14315|FLNC_HUMAN & Decreased \\
Calponin-1 & sp|P51911|CNN1_HUMAN & Decreased \\
\hline & &
\end{tabular}

\section{REFERENCES}

1. Jemal A, Siegel R, Xu J, Ward E. Cancer statistics. CA Cancer J Clin 2010;60:277-300.

2. Hung KE, Yu KH. Proteomic approaches to cancer biomarkers. Gastroenterology 2010;138:46-51.e1.

3. Gygi SP, Rist B, Gerber SA, Turecek F, Gelb MH, Aebersold R. Quantitative analysis of complex protein mixtures using isotope-coded affinity tags. Nat Biotechnol 1999;17:994-9.

4. Vellaichamy A, Sreekumar A, Strahler JR, et al. Proteomic interrogation of androgen action in prostate cancer cells reveals roles of aminoacyl tRNA synthetases. PLoS One 2009;4:e7075.

5. Smith L, Qutob O, Watson MB, et al. Proteomic identification of putative biomarkers of radiotherapy resistance: A possible role for the 26S proteasome? Neoplasia 2009;11:1194-207.

6. Siu KW, DeSouza LV, Scorilas A, et al. Differential protein expressions in renal cell carcinoma: New biomarker discovery by mass spectrometry. J Proteome Res 2009;8:3797-807.

7. Pernemalm M, De Petris L, Eriksson $\mathrm{H}$, et al. Use of narrow-range peptide IEF to improve detection of lung adenocarcinoma markers in plasma and pleural effusion. Proteomics 2009;9:3414-24.

8. Matta A, Tripathi SC, DeSouza LV, et al. Heterogeneous ribonucleoprotein $\mathrm{K}$ is a marker of oral leukoplakia and correlates with poor prognosis of squamous cell carcinoma. Int J Cancer 2009;125:1398-406.

9. Ralhan R, Desouza LV, Matta A, et al. Discovery and verification of head-and-neck cancer biomarkers by differential protein expression analysis using iTRAQ labeling, multidimensional liquid chromatography, and tandem mass spectrometry. Mol Cell Proteomics 2008;7:1162-73.

10. Chen Y, Choong LY, Lin Q, et al. Differential expression of novel tyrosine kinase substrates during breast cancer development. Mol Cell Proteomics 2007;6:2072-87.

11. Lee HJ, Na K, Choi EY, Kim KS, Kim H, Paik YK. Simple method for quantitative analysis of $\mathrm{N}$-linked glycoproteins in hepatocellular carcinoma specimens. J Proteome Res 2010;9:308-18.

12. DeSouza L, Diehl G, Rodrigues MJ, et al. Search for cancer markers from endometrial tissues using differentially labeled tags iTRAQ and cICAT with multidimensional liquid chromatography and tandem mass spectrometry. J Proteome Res 2005;4:377-86.

13. Schlemper RJ, Riddell RH, Kato Y, et al. The Vienna classification of gastrointestinal epithelial neoplasia. Gut 2000;47:251-5. 
14. Compton CC, Greene FL. The staging of colorectal cancer: 2004 and beyond. CA Cancer J Clin 2004;54:295-308.

15. Litwin M, Mazur AJ, Nowak D, Mannherz HG,

Malicka-Blaszkiewicz M. Gelsolin in human colon adenocarcinoma cells with different metastatic potential. Acta Biochim Pol 2009;56:739-43.

16. Noske A, Denkert C, Schober H, et al. Loss of Gelsolin expression in human ovarian carcinomas. Eur J Cancer 2005;41:461-9.

17. Asch HL, Winston JS, Edge SB, Stomper PC, Asch BB. Down-regulation of gelsolin expression in human breast ductal carcinoma in situ with and without invasion. Breast Cancer Res Treat 1999;55:179-88.

18. Gay F, Estornes Y, Saurin JC, et al. In colon carcinogenesis, the cytoskeletal protein gelsolin is down-regulated during the transition from adenoma to carcinoma. Hum Pathol 2008;39:1420-30.

19. Ni XG, Zhou L, Wang GQ, et al. The ubiquitin-proteasome pathway mediates gelsolin protein downregulation in pancreatic cancer. Mol Med 2008;14:582-9.

20. Zamo A, Cecconi D. Proteomic analysis of lymphoid and haematopoietic neoplasms: There's more than biomarker discovery. J Proteomics 2010;73:508-20.

21. Dong Y, Asch HL, Medina D, et al. Concurrent deregulation of gelsolin and cyclin D1 in the majority of human and rodent breast cancers. Int J Cancer 1999;81:930-8.

22. Winston JS, Asch HL, Zhang PJ, Edge SB, Hyland A, Asch BB. Downregulation of gelsolin correlates with the progression to breast carcinoma. Breast Cancer Res Treat 2001;65:11-21.

23. Dosaka-Akita H, Hommura F, Fujita H, et al. Frequent loss of gelsolin expression in non-small cell lung cancers of heavy smokers. Cancer Res 1998;58:322-7.
24. Lee HK, Driscoll D, Asch H, Asch B, Zhang PJ. Downregulated gelsolin expression in hyperplastic and neoplastic lesions of the prostate. Prostate 1999;40:14-9.

25. Rao J, Seligson D, Visapaa H, et al. Tissue microarray analysis of cytoskeletal actin-associated biomarkers gelsolin and E-cadherin in urothelial carcinoma. Cancer 2002;95:1247-57.

26. Visapaa H, Bui M, Huang Y, et al. Correlation of $\mathrm{Ki}-67$ and gelsolin expression to clinical outcome in renal clear cell carcinoma. Urology 2003;61:845-50.

27. Kim JH, Choi YK, Kwon HJ, Yang HK, Choi JH, Kim DY. Downregulation of gelsolin and retinoic acid receptor beta expression in gastric cancer tissues through histone deacetylase 1. J Gastroenterol Hepatol 2004;19:218-24.

28. Yang J, Tan D, Asch HL, Swede H, Bepler G, Geradts J, Moysich KB. Prognostic significance of gelsolin expression level and variability in non-small cell lung cancer. Lung Cancer 2004;46:29-42.

29. Thor AD, Edgerton SM, Liu S, Moore DH II, Kwiatkowski DJ. Gelsolin as a negative prognostic factor and effector of motility in erbB-2-positive epidermal growth factor receptor-positive breast cancers. Clin Cancer Res 2001;7:2415-24.

30. Shieh DB, Chen IW, Wei TY, et al. Tissue expression of gelsolin in oral carcinogenesis progression and its clinicopathological implications. Oral Oncol 2006;42:599-606.

31. Porter RM, Holme TC, Newman EL, Hopwood D, Wilkinson JM, Cuschieri A. Monoclonal antibodies to cytoskeletal proteins: An immunohistochemical investigation of human colon cancer. J Pathol 1993;170:435-40.

32. Zhang L, Zhou W, Velculescu VE, et al. Gene expression profiles in normal and cancer cells. Science 1997;276:1268-72.

33. Bertucci F, Salas S, Eysteries S, et al. Gene expression profiling of colon cancer by DNA microarrays and correlation with histoclinical parameters. Oncogene 2004;23:1377-91. 


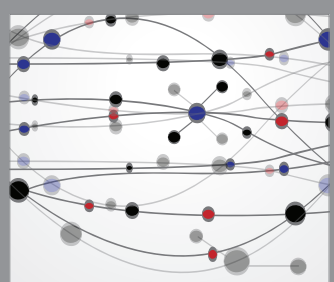

The Scientific World Journal
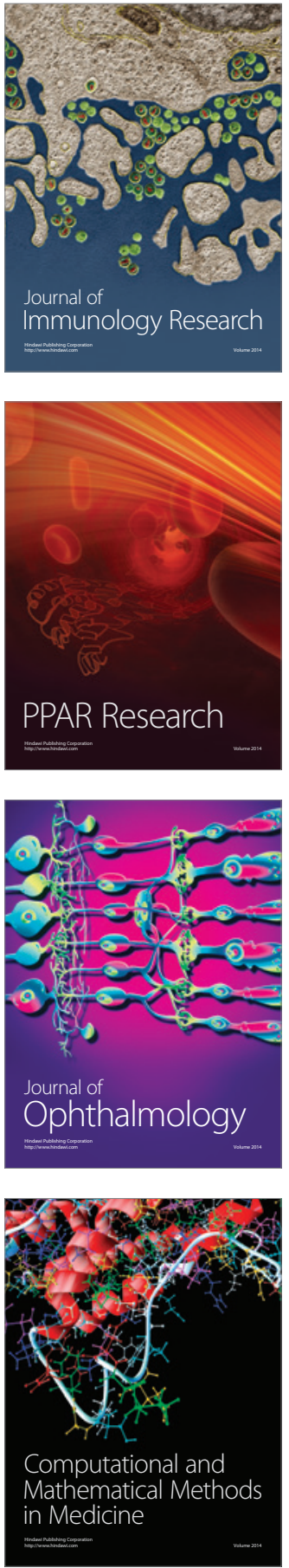

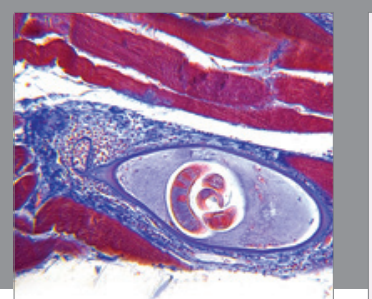

Gastroenterology Research and Practice

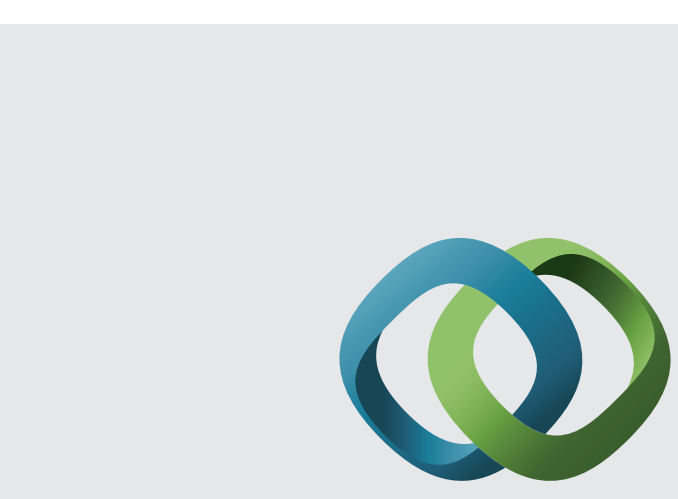

\section{Hindawi}

Submit your manuscripts at

http://www.hindawi.com
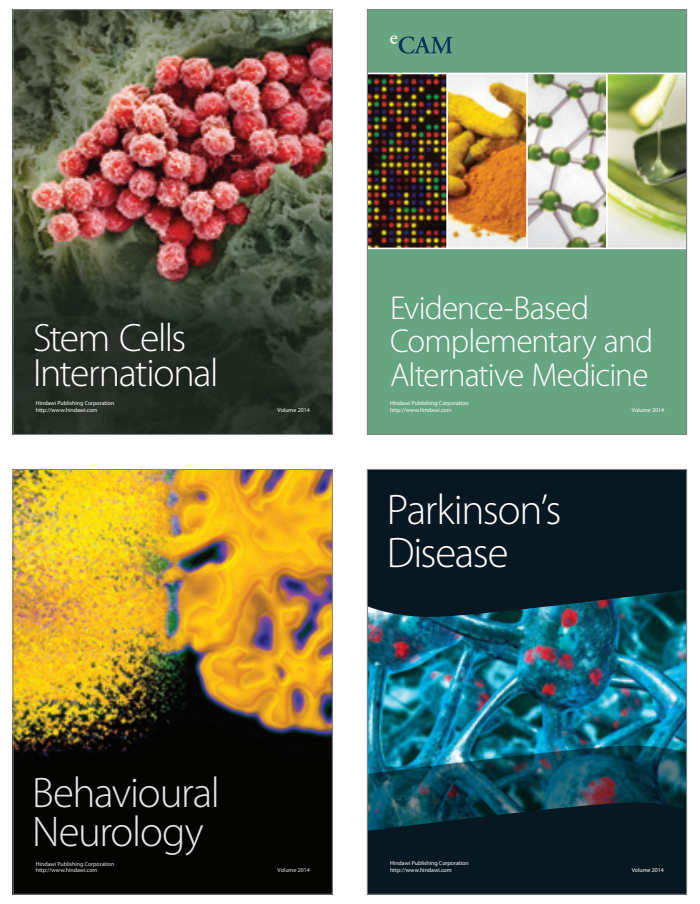
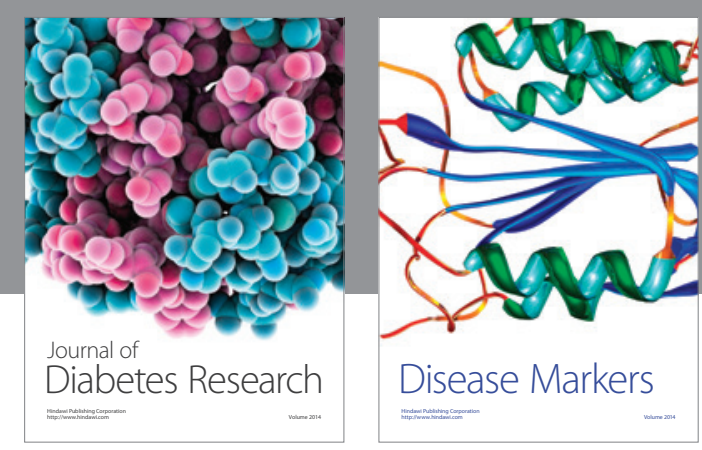

Disease Markers
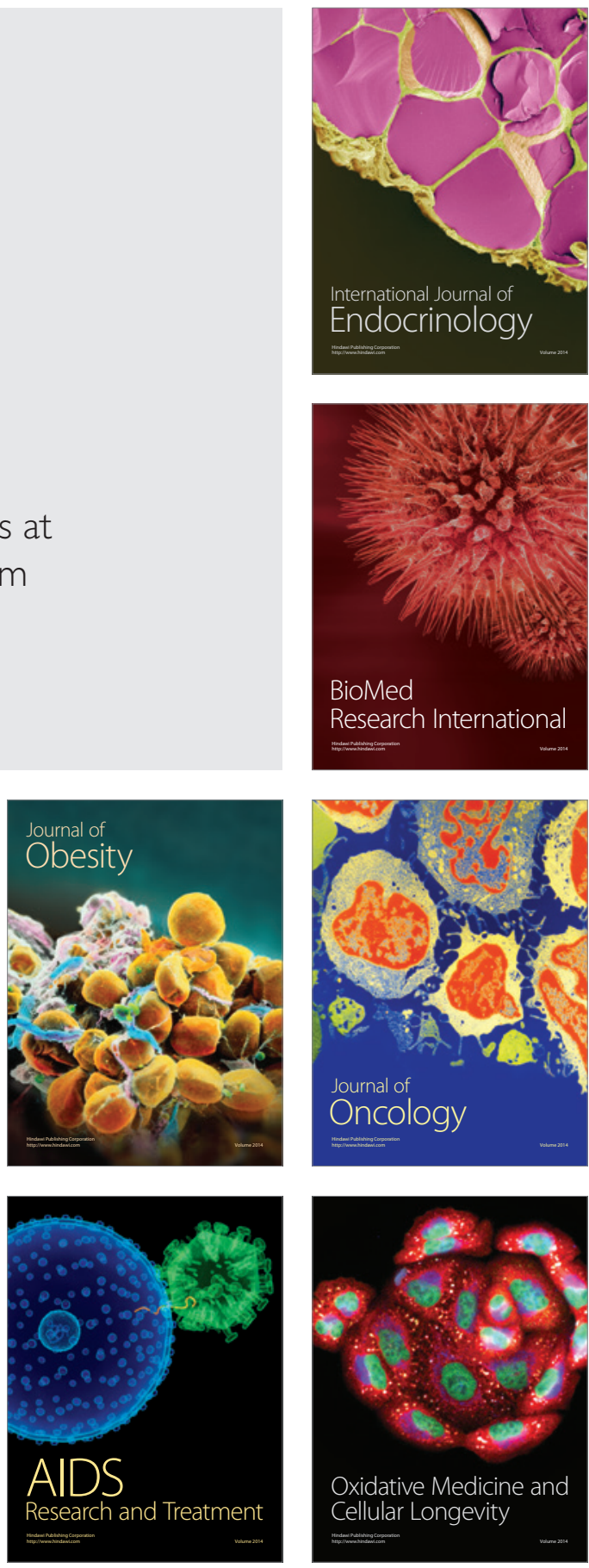